\title{
Micro-Politics and Conflicts in Multinational Corporations: Current Debates, Re-framing, and Contributions of this Special Issue
}

\author{
Christoph Dörrenbächer a and Mike Geppert b,*
}

\footnotetext{
${ }^{a}$ Social Science Research Center Berlin (WZB) Research Unit, Internationalisation and Organisation, Reichpietschufer 50, D-10785 Berlin, Germany and Department of International Business and Management, University of Groningen, Landleven 5, PO-Box 800, 9700 AV Groningen, The Netherlands

${ }^{\mathrm{b}}$ School of Business Management, Queen Mary University of London, Mile End Road, London E1 4NS, United Kingdom
}

* Corresponding author. Tel.: +44-20-7882-7441; fax: +44-20-7882-3615

Email addresses: Doerrenbaecher@wz-berlin.de (C. Dörrenbächer), m.geppert@qmul.ac.uk (M. Geppert)

\section{Introduction}

The topics of this Special Issue, concerned with the socio-political underpinnings of the management and organization of the multinational corporations (MNC), have so far been neglected and marginalized in the broad field of international business (Bélanger and Edwards, 2006; Ferner, 2000; Geppert and Williams, 2006). This is especially true of economic approaches which consider these issues mainly as macro-political effects on foreign direct investments (FDI) and risks of rational decision-making in MNCs. A closer look at three recently published leading handbooks in the field shows that these topics are not considered at all or have been approached either in rather narrow terms or as issues that are distracting and dysfunctional for the effective management and control of the MNC. 
Economic studies of international business organizations theorize micro-politics in terms of externally caused events, such as when efficient decision-making is disturbed or blocked through external events reflecting the macro-political instability of the business environment, especially in certain host countries. Accordingly, micro-politics is discussed in the IEBM Handbook of International Business as 'micro-personal political risks' that managers might face when operating overseas. Thus, micro-political risks are seen 'as dangers that apply strictly to individuals', externally caused for example through politically motivated assassination, political kidnapping and consequent demand for ransom, or instances of forced evacuation from potentially hostile areas (Frank, 1998, p. 409). Given that this definition of micro-politics is a rather specific one and, what is more, far from getting close to any definition used in organization studies (see e.g. Hardy and Clegg, 1996, for an overview), it is indeed surprising that we found in the Oxford Handbook of International Business a brief reference to the topics, but again focusing on the macropolitical dimension of conflicts emerging through FDI in the context of nation states (Spar, 2001, p. 213). Again, in the more recently published Blackwell Handbook of Global Management, our topics are not directly addressed - for instance in a separate chapter and only brief references to organizational politics and conflicts are made in two chapters. One refers to 'managing conflict' in culturally diverse global teams (Davison and Ekelund, 2004, pp. 237-238) and the other to 'resistance' emerging in the creation of global organizations (Osland, 2004, pp. 136-137).

The neglect and marginalization of the central themes of this Special Issue seem to be directly related to the functionalist bias in the mainstream literature of the field. Where power, politics and conflicts are discussed, they are mainly interpreted either as signs of "bad" (dysfunctional) management or simply as a misfit between the organizational design and certain aspects of external environmental features. Traditional research in international management, that draws "eclectically rather then systematically on organization theory" (Ghoshal and Westney 1993, p. 1), tends to use "neutral” terms and talks in terms of creating coherent and integrated management systems that spread transnationally, enable better (efficient) management and balance global and local pressures. In short, what is 
missing in contemporary studies of the MNC is a systematic and in-depth discussion about the role of organizational power, politics, conflicts and resistance in MNCs, despite what Doz and Pralahad (1993, pp. 36-38) in their seminal article foresaw as the importance of these issues in outlining a new research paradigm.

Exactly these concerns led us to organize two events where we focused on the issues of micro-politics and conflicts in MNCs: a subgroup of the annual colloquium of the European Group of Organization Studies in Ljubljana (Slovenia) in 2004 and a panel at the Critical Management Studies Conference in Cambridge (UK) in 2005. Some of the papers in this

Special Issue were presented in Ljubljana and many ideas in this introduction are the result of discussions at both events. We would like to thank all participants for their stimulating contributions.

We start this introductory article by giving a brief overview about how influential noneconomic approaches in international management have addressed the issues of power, politics and conflict in MNCs. The compiled papers in this Special Issue consider some of the shortcomings in the literature primarily from an organization-theoretical angle, but of course they cannot make up for the systematic neglect of these topics in existing international business research. We go on to indicate, however, where the contributing papers open up new ways of examining and researching micro-politics and conflicts in MNCs, both conceptually and empirically. Here we distinguish three conceptual frames of analyzing power, politics and conflicts in the MNC. In our concluding remarks, we propose possible directions for future research.

\section{Power, politics and conflicts in MNCs: A brief overview}

The mainstream literature was dominated for a long time by contingency approaches to the MNC. Leading scholars in the field, where they referred to power, politics and conflicts in MNC at all, discussed these issues predominantly from a functionalist perspective. Early approaches tended to see power and politics as phenomena which can be best tackled by adapting formal structures to address (more or less) stable or dynamic environmental 
characteristics (e.g. Stopford and Wells, 1972). Power and influence were understood to be distributed along traditional hierarchical lines, with the headquarters (HQ) as the central authority formally making all strategic decisions and the subsidiaries mainly responsible for operational tasks. The key problem of HQ management was to balance local demands and resources with the global strategy of the firm (e.g. Kilduff, 1993). Politics and conflicts were not denied, but only interpreted as functional as long as they did not question the centrality and authority of HQ management to find the optimal solution for the local-global dilemma and, accordingly, the "optimal fit” to meet the environmental pressures of a more or less globalized task environment.

In the studies that followed Bartlett and Ghoshal's (1989) “Managing Across Borders”, the traditional view of the superiority of HQ management was not replaced but it was questioned and supplemented by a more pluralist view of power relations. In this perspective, the formal power of the HQ was understood to be limited. Global environmental pressures of markets, new technologies and even cultural convergence across national borders were seen as responsible for the emergence of transnationally 'differentiated networks' (Nohria and Ghoshal, 1997) and the 'diversified multinational corporation’ (Doz and Prahalad, 1993), in which power structures were more ambiguous and decentralized. However, few researchers directly addressed the new role of power and politics in this more informal and fragmented transnational organizational form. Bartlett and Ghoshal (1989) obviously preferred to discuss these issues in neutral terms, by referring to the appearance of organizational and cultural 'barriers' when developing the 'transnational solution' and to the problems of how newly created decentralized subunits gain access to critical resources and strategic decision-making. However, in many studies examining new organizational forms in transnational firms, such as Nohria and Ghoshal's (1997) “The Differentiated Network”, one could even go so far as to ask whether the authors deliberately avoided associating their research with issues of power and politics identified by Hardy and Clegg (1996). Such studies normatively presuppose that powerful HQ or subsidiary managers are able to coordinate and control the new organizational forms through socialization, shared values and normative integration. The underlying logic is that 
managing the transnational culture will improve inter-functional and inter-departmental, HQ-subsidiary and inter-subsidiary communication (Nohria and Ghoshal, 1997, pp. 93149). A basic assumption seems to be that if managers develop a better understanding of the ‘transnational solution' and better address cross-cultural and cross-divisional conflicts, the dysfunctional effects and illegitimate aspects of politics and power will hardly ever appear - they may even disappear. Such views fail to consider questions about whose interests are served by measures of cultural integration, who are the winners and losers when new inter-functional and HQ-subsidiary communication structures are implemented or how the work design and work tasks of non-managerial employees are affected.

After reviewing international management publications, we think it no accident that - given the quantitative bias in top-ranking journals in the field such as the Journal of International Business Studies (Welch and Welch, 2004) - there are very few scholars developing an awareness of the increasing importance of power, politics and conflicts in newly emerging transnational organizational forms. Even though the topics of this Special Issue are indeed under-researched, we can identify two existing research streams, drawing on organizationtheoretical ideas in studying the MNC, which have begun to address the themes. First, there are studies in the tradition of the so called 'evolutionary model', which are interested in the political nature of the economic success of subsidiary-led innovation processes and entrepreneurship. Second, institutionalist studies of MNCs raise the political dimension of non-economic contextual rationalities that are related to home, host and third country institutional influences on the management of subsidiaries.

The first stream of research stresses that traditional hierarchical power relations with the HQ as the key player are in decline because of the increasing pressure of globalized markets and technologies. They argue that the traditional hierarchical structures of the MNC based on formal authority relations between the HQ and its subsidiaries will be replaced by more de-centralized structures based on new and more complex interdependencies. It is expected that new power games and, accordingly, a greater variety of new power players emerging in these more decentralized MNCs require future research 
attention in international management studies. Thus, Doz and Prahalad (1993), for example, argue that the diversity of power players and the personal strategies of local managers might matter more than those of HQ, depending on their own goals and the resources they control. The resources that subsidiary managers can draw on, however, could be both internally and externally based, an issue which is emphasized in a study analyzing the success and failure of entrepreneurial initiatives of subsidiaries. The authors argue that MNCs have an internal 'corporate immune system', a mixture of structural and cultural inertia, that blocks entrepreneurial initiatives and innovation (Birkinshaw and Ridderstrale, 1999). This analysis based on case studies shows that internal resistance against subsidiary initiatives was expressed both from the HQ and from other subsidiaries competing for critical resources, and found that legitimizing new initiatives internally was more successful when circumventing the MNCs 'immune system'. It was easier to legitimize a project that had already gained outside allies and proven to have market acceptance. Furthermore, the study of Forsgren (1989, p. 77) shows that micro-politics in subsidiaries cannot only be explained as 'a general striving for autonomy’ within the multinational itself; political 'tensions' also arise due to changes in the industrial network and local market in which a subsidiary is embedded. Forsgren et al. (2005) develop these ideas further. The empirically based study shows that the political influence of the subsidiary management and its functional importance within the MNC are closely linked to its embeddedness within both the corporate and the wider business network. Thus, unlike traditional studies addressing power issues in MNCs, Forsgren and his colleagues (2005, p. 128) give environmental contingencies 'a face'. However, when rejecting the static top-down model of HQ power relations, these authors stress the influence of social networks and the importance of decentralized bargaining and negotiations, often de-centrally initiated by certain subsidiaries. However, a more detailed consideration of these negotiations is still missing.

The nature of subsidiary power and the problems of local managers trying to influence corporate decisions and rules is another topic in this Special Issue. The papers of Dörrenbächer and Gammelgaard and Taplin discuss strategies and power games of subsidiary managers. Taplin shows that more participative management concepts initiated 
by the HQs of textile firms do not necessarily support subsidiary managers in improving their current power base. For example some managers resisted the implementation of more flexible and de-centralized management modes to sustain or even improve their dominant positions, both within their local subsidiary and in relation to the HQ. The paper of Dörrenbächer and Gammelgaard shows that even in cases where foreign subsidiaries lack the power resources to influence HQ decisions, local mangers were able to get engaged into micro-political bargaining processes. This appeared to be crucial for them, since it was often the only way to make their counterparts in the HQ aware of the rather hidden capabilities of their subsidiaries and certain strategic options that lie beyond the immediate interests of the HQ.

The second stream of research probably cannot yet be called mainstream within the field. Institutionalist approaches have only recently acquired importance in studying the MNC from an organization theoretical perspective, beyond the still dominant evolutionary school. While scholars of the first research stream emphasize the role of resource dependencies on the political influence of the various functional and regional subunits within the MNC, institutionalist researchers take a broader perspective, stressing the importance of the institutional embeddedness of the MNC as a whole and of its parts, such as the HQ and the subsidiaries. Emphasizing institutional environments, it is basically argued that a high degree of 'institutional distance' (Kostova and Zaheer, 1999) between the HQ and its subsidiaries causes problems for the MNC as a whole in achieving legitimacy, externally in the host country and internally within the MNC itself. Accordingly, various studies have found that both the home country institutions and the host country institutions, such as the educational system, the system of industrial relations, the financial system and the industrial policy of the national government - influence the MNC's forms of control (e.g. Dörrenbächer, 2000; Harzing and Sorge, 2003), work systems (e.g. Geppert et al., 2003), production systems (e.g. Hollingsworth and Boyer, 1997) and employment practices (e.g. Edwards and Ferner, 2002). However, similar to the research on the evolution of the MNC, issues of power and politics have only rarely been considered. Only recently, have institutionalist researchers started to shed some light on the political nature of 'contextual 
rationalities' (e.g. Morgan, 2001), micro-political game-playing, the emergence of 'battlefields' (Kristensen and Zeitlin, 2001) and political issues in sensemaking (e.g. Geppert, 2003) in MNCs. Research has identified the emergence of 'transnational social spaces' in and around MNCs, which can be understood as arenas for political strategizing and power play. On one hand, national institutions have been shown to have continuing influence, for example, by providing host country managers with critical resources enabling them to resist HQ influences (e.g. Williams and Geppert, 2006). On the other hand, these studies have also found cases of misunderstandings between the HQ and its subsidiaries and between managers in different subsidiaries, creating 'battlefields' and severe conflicts (e.g. Kristensen and Zeitlin, 2001, 2005).

Consideration of these issues is taken further in this Special Issue from more conceptual perspectives. Drawing on a combination of Scandinavian institutionalist research and structuration theory, Becker-Ritterspach (in this Special Issue) provides a framework to understand knowledge integration in MNCs as a dialectic transformation process that is constituted by human actors and social systems. The author argues that actors or groups of actors are differently affected and able to shape such processes on the basis of their organizational positioning. These matters are explored from another angle by Clark and Geppert (in this Special Issue), who focus on processes of institutional order-building in international ventures of Western MNCs in post-communist countries. They argue that the specific interplay between the strategic orientations of senior MNC managers and local managers' perspectives strongly influences the emergent states of order or disorder in these international ventures. The interaction between foreign and local influences is also at the heart of the empirically based paper by Sharpe (in this Special Issue). This ethnographic study deals with management-worker relations on different sites of a Japanese MNC in the UK. Here, micro-political processes initiated by the management to gain social control over workers' behavior and beliefs were balanced by the workers' labor market experiences and their embeddedness within the wider societal culture, leading to both conflicting translation processes and 'parallel universes'. 
After showing the lack of systematic and in-depth research on power, politics and conflicts in MNCs and referring to some recent conceptual and empirical developments, we will briefly outline what research genuinely focusing on micro-politics and conflicts in the MNC encompasses, including some considerations of its theoretical foundations, emerging empirical questions and methodological problems.

\section{Micro-politics and conflicts in MNCs: Theoretical foundations, genuine empirical questions and methodological problems}

The focus on micro-politics in MNCs is first and foremost about bringing back the actors and examining the conflicts that emerge when powerful actors with different goals, interests and identities interact with each other locally and across national and functional borders. Despite some general claims to have incorporated actors' strategies and interests (Doz and Prahalad, 1993) and a general rethinking of the mainly context-based understanding of organizations in terms of action theories since the 1980s, most empirical studies of organizational design and MNC strategies are still strongly influenced by contingency theories. Missing basic foundations of action theory, the actors involved in these studies remain relatively 'faceless', characterized on the whole one-dimensionally in terms of their actions or their (sub)organizational affiliation, or according to universal behavioral assumptions such as a general knowledge sharing hostility (Husted and Michailova, 2002) or a "not invented here” attitude (Edwards et al., 1999; Forsgren et al., 1995). In contrast, genuine micro-political approaches do not see individual or corporate actors as merely executive organs of external institutional and task environment features. Instead, they conceptualize actors as being informed by structural and institutional constraints but at the same time taking into account their subjective interests in organizing and strategizing. Very often those interests are self-centred, defined genuinely by issues of gaining power and autonomy, and by career ambitions within in a certain subsidiary or within the MNC as a whole. However, they might also be shaped by altruistic ideas and beliefs (Ortmann, 1988), personal identity construction (Weick, 1995) or group dynamics (Lee and Lawrence, 1985). 
Like all other forms of politics, organizational micro-politics are understood as an attempt to exert a formative influence on social structures and human relations. Securing options, realizing interests, and achieving success however take place in a contested terrain. Thus micro-political conflicts are everyday occurrences which can appear in every organization, including in MNCs. Moreover, these conflicts are a fundamental mechanism of social interactions which either can hold organizations together or lead to fragmentation and disintegration. Micro-politics can affect an MNC as a whole, for example, when they concern global business strategy. However, they also apply to medium range issues, such as when decisions are about the location of economic activity or the re-grading of subsidiary functions and mandates. Finally, micro-political conflicts occur at the departmental level in either the HQ or the subsidiaries, for instance over the development of external (international) contacts or the negotiation of budgetary issues.

Despite a great variety of micro-political issues in MNCs, it is widely acknowledged that only a few powerful key actors usually get actively involved in micro-political strategizing, yet their interactions can have far-reaching consequences for all members of the organization (Burns, 1961). On the premises of strategic organizational analysis, which roots micro-political behavior of actors in the organizational framework of action, executives from both the HQ and subsidiaries seem to be the main "political brokers" (March, 1962, p. 672) in MNCs. Micro-politically inspired research has concentrated on these actors, since it is their respective orientations and strategizing that shapes the development of the MNC, reflecting an amalgam of 1) internal structures, coalitions and power relations, 2) external stakeholders' interests and 3) subjective concerns about power, autonomy and career development.

Theoretically, micro-political approaches touch upon determinism and voluntarism, integrating structural and action perspectives through the concept of micro-political games (Crozier and Friedberg, 1980). During these games - a large number of which are played both simultaneously and successively - the actors are bound by rules, restrictions and resources. However, these structural limitations also provide certain liberties (with actor- 
specific differences) that can be used for the implementation of actors' tactics and strategies. According to Mintzberg (1983, p. 188), authority games, power building games, rivalry games and change games are of a special significance in organizations. Other authors distinguish between routine and innovative games or give a rather functional list including budgeting games, career games and reorganization games. Further investigation is required to determine more precisely what specific internationalization games exist in MNCs and what their characteristic features are. To be sure, internationalization issues do play a particularly important part in other games, for instance, in budgeting (Kristensen and Zeitlin, 2005) or career games (Dickman and Harris, 2005; Feldman and Thomas, 1992). But there are also strong arguments in support of the assumption of genuine internationalization games played by the main political brokers in MNCs, i.e. HQ and subsidiary managers.

For instance, according to Morgan and Kristensen (2006, forthcoming), the outstanding position of the HQ in terms of power and access to distant units of the MNC allows HQ managers to play the 'language game on globalization'. That is, they use the globalization metaphor to assert HQ’s interests in global standardization processes. Moreover, HQ managers are able to exploit their exclusive relationship with the shareholders of the MNC to impose the 'investment bargaining and regime shopping game' on its subsidiaries, using shareholders' interests in return on investment as an argument to legitimize restructuring, internal investment competition and related benchmarking activities all over the MNC.

Subsidiary managers in MNCs can also play internationalization games. In one game the local managers act as "interpreters" of rules of the game, which are often developed elsewhere and transferred locally in the MNC (Ferner, 2000). For example, the affiliation of expatriates to the HQ on the one hand and to the foreign subsidiary on the other is a situation that presents tactical and strategic alternatives otherwise unavailable in the national framework. Subsidiary managers can weaken, modify or ward off disagreeable and unreasonable requests from HQ by referring to the institutional structures in their country or to the political power of local actors in certain circumstances (for examples, see Becker- 
Ritterspach et al., 2002; Tempel, 2001). They can, for example, exploit existing differences in national work regulations. However, they can also functionalize the peculiarities of the 'insecurity zone’ (Crozier and Friedberg, 1980) that HQ managers in MNCs see themselves confronted with while controlling their subsidiaries, a game which capitalizes foreignness.

Further research opportunities are not restricted to better elucidation and detection of new internationalization games. More empirical research and theorizing are especially needed with regard to actor rationales, communication and influence strategies and questions of MNC configuration.

Up to now, most research on MNCs assumes that the rationales of the actors are shaped by contextual features of the organizational subunit to which they belong. Thus traditional research operates with quite restrictive assumptions about the relationship between actors and their organizations, neglecting the important impact of diverse rationalities which are shaped both socially and societally. All papers in this Special Issue clearly demonstrate these impacts. They demonstrate that changes of organizational structures and decisionmaking processes require a less deterministic and more dialectical view of what constitutes learning and knowledge transfer across national and functional boundaries. From this perspective, actors are not 'faceless' as assumed by universalistic research on MNC evolution or in institutionalist studies on path-dependency. Focusing on the rationales and interests of key actors when developing strategies is about analyzing micro-political strategizing processes and the interaction of different key actors and their attempts to impose, negotiate, resist, accept or oppose certain rules of the game. Thus, compared to mainstream studies of political issues in MNCs, changes of organizational design and strategies in MNCs are understood not just as being externally constrained. Rather, political actors are pursuing their interests by enacting structural constraints (e.g. rules and resources) during micro-political games in the process of accepting or opposing the strategic approaches of the HQ and of other powerful internal and external stakeholders. 
This leads us to a second area where more empirical research and theorizing are needed, namely the power strategies that actors use to influence the rules of the game. The extent to which actors are able to set their own rules of game, or in other words, the extent of their assertive power, depends on the degree of control over the insecurity zones in question. This has to do with the fact that potential antagonists in MNCs control areas or resources that one needs to set one's own rules. The manner in which actors or groups of actors try to exert influence across geographical, political, socio-economic, cultural and religious distances associated with internationalization processes has so far been quite neglected. At any rate, one can expect different interests and strategies in developing rules at a more local or a more global (HQ-) level, for HQ and subsidiary managers and for different types of subsidiary managers (expatriates, locals bi-nationals, third country nationals). Differences might also be promoted by the overall strategic approach of the MNC. Thus, one can expect different requirements and possibilities for local managers in setting and negotiating their own rules in MNCs that apply a "polycentric-exploratory" strategy compared to MNCs with an "ethnocentric-exploitative” approach (see Clark and Geppert in this Special Issue).

Both actor rationales and strategies to influence rule-setting in the MNC also remain dependent on the specific home and host country configuration, in which a micro-political game or conflict is embedded. The question as to what are relevant country-of-origin effects in micro-political game-playing is as open as the question of what role the host country plays. Harzing and Sorge’s findings (2003), for instance, showed quite strong country-of-origin effects on control strategies, which are well known to lead to frictions in MNCs. Morgan and Kristensen (2006, forthcoming) point to significant country-of-origin differences in shareholder value pressure and hence in the need for corporate restructuring and investment bargaining, two other well known causes of micro-political conflicts in MNCs. With regard to host country implications, the contributions of Forsgren (1990) and Dörrenbächer and Gammlegaard (in this Special Issue) highlight the role played by the stage of economic development of a host country in micro-political game playing of local subsidiaries, but further refinements in future research are needed here. 
Last but not least, we want briefly to refer to the methodological problems emerging for ongoing and future research dealing with micro-politics in MNCs. These should not be underestimated given the traditional bias of quantitative studies in the field of international business. A qualitative project dealing with micro-politics in MNCs can be a challenging and sensitive enterprise in terms of gaining access, convincing HQ and subsidiary managers to take part and getting respondents to talk openly about these topics (Fischer, 2005). Micro-political conflicts in MNCs are also full of ambiguity and divergent interpretations. Interview partners are often reluctant to speak about their own and other important key players' political strategies and interrelated conflicts. There are also problems arising from the many different languages as well as national and cultural contexts involved. Another methodological problem is validation, triangulation and generalization from the small number of cases studied. For most these problems solutions are at hand. Access is possible to more amenable companies, at least if anonymity is credibly assured. A multilingual, self reflecting team of researchers might cope with some of the ambiguity and sensitivity of issues, while the mastering of a wide set of quantitative and qualitative methods might help to overcome validation, triangulation and generalization problems. Thus, although researching micro-politics in MNCs might be a risky and sometimes difficult endeavor, the papers in this Special Issue demonstrate that undertaking such research is not only possible but can also provide many fascinating and new insights into the management of the MNC (see also the concluding discussion in the paper of Becker-Ritterspach in this Special Issue).

Next, we shed some light on how the contributions of the papers in this Special Issue fit within this emerging field of research and make some concluding remarks, briefly summarizing what we have learned and exploring possible topics for future research.

\section{Re-framing micro-politics and conflicts in MNCs: The contributions of this Special}

\section{Issue}

Leading scholars studying organizational power and politics have criticized dominant functionalist studies for having mainly adopted a managerialist orientation for which the 
underlying assumptions are rarely articulated (Hardy and Clegg, 1996, p. 63). Thus, is the first contribution of this Special Issue. All papers are dealing with managerial problems, but they are doing so in a less functionalist and deterministic manner, as critics rightly call for. All papers address the underlying assumptions and diversity of strategies of key actors actively involved in various micro-political games in the MNC. Moreover, some papers (e.g. Sharpe or Becker-Ritterspach in this Special Issue) also identify the importance of considering the interests of other groups of employees when analyzing micro-politics and conflicts. A second contribution of this Special Issue is that all papers directly address the political nature of strategizing by key actors, an issue either neglected or interpreted as dysfunctional in mainstream studies of the MNC.

Despite the fact that all papers deal with organizational change processes, it is evident that organizational power, micro-political strategizing and conflicts are differently conceptualized in each of the papers. To uncover their coherence and to elucidate the key ideas, we use Rothman and Friedman's (2001) attempt to classify conflicts and politics in organizations in relation to the underlying concept of organizational power. According to these authors, we can distinguish three focuses of micro-political strategizing and conflicts: resources, interests and identities.

The first identified way of framing is around resources (Rothman and Friedman, 2001, pp. 585-587). In this perspective, micro-political conflicts and game playing focus on scarce resources and strategic goal setting in the MNC, aiming to increase the organizational power and autonomy of certain actors and groups of actors. Power is understood as the degree to which actors are able to access, protect and control scarce resources. Unlike former waves of empirical research, that gave the impression that such conflicts are either triggered by the HQ or by subsidiaries, the papers of this Special Issue, provide evidence that such conflicts might be triggered and continuously shaped by both HQ and subsidiary interactions. The papers of Dörrenbächer and Gammelgaard and Taplin are especially concerned with resource conflicts. 
Christoph Dörrenbächer and Jens Gammelgaard's paper studies subsidiary role development and found that the desire of local subsidiaries to keep or to upgrade their position within the MNC sometimes led to harsh clashes of interests. Based on an empirical study in Hungarian subsidiaries and their German HQs, the paper reveals firstly that, together with subsidiaries' capabilities and localization advantages, HQ intended strategies were especially decisive in explaining role development in peripheral host countries. Secondly, micro-political HQ-subsidiary negotiations were an integral part of subsidiary role development because these bargaining processes were often the only way for subsidiaries to make explicit their capabilities to the HQ and introduce strategy options that lay beyond or even contradict HQ intended strategies.

Ian Taplin's paper in this Special Issue discusses the distribution and control of subsidiary power resources emerging in change management processes in the US textile industry. Comparing HQ inspired reorganization programs towards high performance work practices in foreign and national textile companies in the US, the author sheds light on the often subtle micro-political games, that subsidiary managers play by manipulating and interpreting the information surrounding the implementation of such programs. He concludes that the extent to which subsidiary managers can thereby justify self-serving actions - for instance by resisting the implementation of such reorganization measures depends largely on the autonomy granted to them by the HQ.

A second way of framing micro-politics and conflicts assumes that gaining or losing power is not so much about resources, but is caused by a diversity of interests among key players (Rothman and Friedman, 2001, pp. 588-590), related to various cultural, institutional and situational dynamics. This is also a core concern of recent institutionalist studies mentioned above. At the centre of analysis are the different bargaining strategies of key actors and the question of how they can be integrated or moderated. Interest conflicts are driven by different worldviews of key actors, and micro-political games are about local and global power sharing and not so much about who is gaining or losing power. Power is framed as 'concertive', which means that actors try to develop a shared understanding, assuming that 
each party's interests are served by embracing conformity and obedience to authority, controlling conflict, and sometimes reducing or resolving it through collaboration in decision-making. Most of the papers of this Special Issue focused primarily on such ideas and research questions. We have two theoretical contributions, both of which address the problem of knowledge transfer in the MNC. There are also two empirical studies related to this frame, both in the car industry.

Ulla Mense-Petermann's paper focuses on intra-organizational conflicts arising during the process of organizational transnationalization in two Latin American subsidiaries of a German car manufacturer. The author maintains that conflicts might be labeled as either micro-political or inter-cultural, depending on how key organizational actors reflexively enact the process of transnationalization. Conflicts are likely to be thought of and labeled as intercultural when the transnational integration process is led by many expatriates and when there is no rule system commonly accepted by both the local subsidiary members and expatriates. In contrast, conflicts are more likely to be thought of and labeled as micropolitical, when the transnational integration is either led by local managers or when a common rule system exists.

Diana Sharpe presents an ethnographic study of power and micro-politics within two UK subsidiaries of a Japanese automotive company. Drawing on a variety of concepts such as contextual rationality, contested rationality, institutional theory and labor process theory, the paper sheds light on how and why HQ inspired managerial control strategies were resisted and partially rejected on the shop floor. Sharpe argues that, while there was little collective resistance in the subsidiary that challenged managerial authority and the production process itself, the attempt of management to gain social control by transferring certain home country based ideas failed due to the workers' embeddedness in their wider local context, including experiences with the labor market and industrial relations climates.

The paper by Ed Clark and Mike Geppert is about bargaining and negotiation processes between the Western HQ and post-socialist subsidiary management and is concerned with 
institution-building, knowledge transfer and micro-political strategizing. According the authors, international ventures in transition and other emerging economic contexts are typically based on asymmetrical power relationships, in which the balance of power is structurally weighted in favor of the HQ. Notwithstanding this dominance structure, the paper demonstrates that the strategic orientations of senior managers representing the Western MNC and managers representing the local enterprise - as well as the specific combination of these orientations and interests - provide a conceptual basis from which to explain the emergence of types of institutional order or disorder in post-socialist sites.

The other conceptual contribution of this Special Issue deals with transfer problems in MNCs and stresses the discursive and dialectical nature of this process. Drawing on and integrating Scandinavian institutionalism and structuration theory, Florian BeckerRitterspach agues that games about knowledge integration are a crucial part of knowledge transfer in MNCs and must be understood as a 'dialectic transformation' that is constituted by human agency and embedded in social systemic contexts. According to this view, tangible actors and their social-systemic positioning are central to the analysis of micropolitical conflicts and their outcomes in MNCs.

A third mode of framing relates micro-politics and conflicts to the reflexive creation of actors' identities in organizations (Rothman and Friedman, 2001, pp. 590-593). Power is understood as 'relational' and requires analysis to go beyond competition for scarce resources or negotiating interest conflicts. The ‘identity’ frame is about challenging established and institutionally embedded local practices and is theoretically closely linked to ideas of action research, in which conflict is seen as an 'intervention' mechanism to create reflexive forms of organizational learning, e.g. double-loop learning (Argyris and Schön, 1996). At the centre of this perspective are conflicts that help to change the rules of the games and the identities of the involved actors. This appears to be highly relevant to MNCs that try to develop measures for intercultural learning or conflicts that arise from social integration measures. It is assumed that 'better' conflict management is not sufficient and that an alternative 'allowing each party involved to speak about their needs and values 
in the presence of their adversaries' is required to stimulate learning (Rothman and Friedman, 2001, p. 591). In this process, actors will learn more about themselves and other players involved. We can assume that applying such an interventionist approach is quite demanding and sometimes impossible to organize for an MNC as a whole organization. However, such conflicts are crucial in building corporate identity across borders and hence need to be dealt with in a sensible way.

Looking closer at the contributions to this Special Issue, it is noticeable that no author directly addresses identity conflicts. However, most papers refer indirectly to this problem and the lack of reflective learning and broader participation in decision-making across borders. This is rather obvious in the case of the two conceptual papers of this Special Issue. Both papers concentrate on the transfer of knowledge across borders and the necessity of local translation, where identity conflicts can be expected. Becker-Ritterspach finds that structural distance between the societal contexts, between the subunits within the MNC and within the subunit itself (e.g. in a local subsidiary) is crucial to understanding how political actors create their identities and how they learn. He emphasizes especially that positional power resources and personal features of key actors must be considered in order to understand whether and why knowledge transfer leads to conflicts and micropolitical infighting. Clark and Geppert argue in the same direction by stressing that the mutual involvement and learning of managers from both the Western HQ and the local subsidiaries in post-socialist subsidiaries are crucial for transnational institution building. On one hand, less reflective modes of learning can be expected when the HQ imposes ethnocentric strategies, leading to both severe conflicts and game-playing to secure and gain resources. On the other hand, a more exploratory and polycentric strategic approach may be expected to support more reflective learning modes, not just between Western and post-socialist managers, but also locally between managers and other employees and groups of employees.

\section{Concluding remarks}


The basic difference between the papers collected in this Special Issue and mainstream IM approaches is that they treat micro-politics and conflicts as an unavoidable social reality and a natural mechanism of social interactions in MNCs that need to be further explored. Thus an a priori neutral position is taken in preference to regarding micro-politics and conflicts in MNCs as dysfunctional, the result of poor integration or as whatever caused a misfit with structural contingencies. Instead, all papers conceptualize micro-politics and conflicts to be normal consequences of managing and organizing across national borders and of tackling the subtle global integration-local responsiveness dilemma. The evolving picture of the MNC is that it is far from being a functional and 'faceless' organization but must rather be characterized by manifold and ongoing 'ruptures, breaks and inconsistencies in the social fabric' (Hatch, 1997, p. 321).

There are two levels relevant in the analysis of micro-politics and conflicts in MNCs. The first is about studying culturally and societally shaped conflicts and distinguishes different levels of 'structural distance’ (e.g. Becker Ritterspach in this Special Issue). Here, we can expect genuine internationalization games, specific to the context of the MNC. The second level of analysis is concerned with the level of the subsidiary itself, where concepts developed elsewhere require local adaptation and translation, which processes often involve conflicts. Micro-political games at this level can also be very specifically related to the MNC but they can also be very similar to games played in organizations in general and, thus can be compared to those classical studies of Mintzberg and Crozier and Friedberg, as discussed earlier.

In the last section we emphasized that the role of conflicts and micro-political gameplaying can be interpreted differently, dependent on how power and politics are conceptually framed. Most of the contributions of this Special Issue deal with resource and interest conflicts, although, they make implicit references to the issue of identity conflicts and its micro-political implications. 
Finally, we want to raise three issues relevant for future research. First, the narrow focus of the relatively few studies addressing micro-politics and conflicts in MNCs must be broadened. A more pluralistic approach would help to understand and tackle more successfully the complexity of these topics. Current streams of research concentrate either mainly on resource conflicts, as for example in studies of political issues of subsidiary evolution or on institutionally generated interest conflicts in the MNC. However, papers in this Special Issue that relate micro-political conflicts to subjective and collective identities are a first step away from the structuralist bias in current international management research. There is a dearth of more in-depth research on micro-political processes around changes of subjective and collective identities of key players within a local subsidiary and between the HQ and a particular subsidiaries.

Second, this type of research would also involve the move away from a primary focus on managerial influences in micro-political strategizing. Managers are often seen as the most powerful players, but this is only because deeper roots of identity conflicts are not taken into consideration. Thus, future research must broaden its view of the micro-political arena, by including, for example, questions about why and how other stakeholders such as shareholders or subsidiary employees get involved in or are not able to influence crucial aspects of certain micro-political games that enable or block reflective learning across organizational and national borders. Such an approach would question not only the authority of the HQ but also the authority and role of local managers and employees.

Third, future research must also concentrate on the question of how key actors actually bring structures into play. This requires more research applying approaches that are less deterministic than those common in international business studies. Many of the contributions to this Special Issue show that conflicts and micro-political strategizing about resource allocations between HQ and subsidiaries might remain crucial in the MNC. However, more in-depth research is required to analyze how and why key actors in certain situations accept or resist certain HQ strategies. Moreover, we need more comparative research studying how certain interest conflicts are related to specific home country 
features, such as coordination and control strategies which are likely to lead to more reflective learning between geographically and functionally separated subunits of the MNC and thus probably to more constructive solutions of emerging identity conflicts. Other comparative studies might concentrate on analyzing host country and company specific influences that enable or hinder local strategizing and identity construction.

\section{Acknowledgements}

The editors would like to thank all reviewers of this Special Issue, who are Jennifer Bair, Karoly Balaton, Katharina Bluhm, Julia Connell, Wolfgang Dorow, Geert Duysters, Tony J. Edwards, Jörg Flecker, Dirk-Ulrich Gilbert, Paul N.Gooderham, Ulf Holm, Ulrich Jürgens, Ans Kolk, Michael Mayer, Eli Moen, Guglielmo Meardi, Kathleen Park, Arvind Parkhe, Markus Pohlmann, Tony Royle, Ayse Saka, Mitchell Sedgwick, Konstanze Senge, Anna Soulsby, Heinz-Josef Tüselmann and Karen Williams, for their very valuable contribution. We would also like to thank Mike Kotabe and Ram Mudambi in supporting us to make this Special Issue possible. We are also grateful for the editorial assistance of Sylvia Pichorner, Cly Wallace-Aramian, Sebastian Dieng and Kim Cahill. Finally and equally important, we are indebted to our colleagues, Florian Becker-Ritterspach, Ed Clark, Sigrid Quack and Karen Williams, for their constructive comments and suggestions on the first draft of this introductory paper.

\section{References}

Argyris, C., Schön, D.A., 1996. Organizational Learning: Theory, Method and Practice, vol. 2. Addison-Wesley, Reading, Mass.

Bartlett, C., Ghoshal, S., 1989. Managing Across Borders: The Transnational Solution, second ed. Harvard Business School Press, Boston.

Becker-Ritterspach, F., Lange, K., Lohr, K., 2002. Control mechanisms and patterns of reorganisation in MNCs, in: Geppert, M., Matten, D., Williams, K. (Eds.), Challenges for European Management in a Global Context. Experiences from Britain and Germany. Palgrave Macmillan, Houndsmills, pp. 68-95. 
Bélanger, J., Edwards Paul, 2006. Towards a Political Economy Framework: TNCs as National and Global Players, in: Ferner, A., Quintanilla, J., Sánchez-Runde, C. (Eds.), Multinationals, Institutions and the Construction of Transnational Practices. Convergence and Diversity in the Global Economy. Palgrave Macmillan, Houndsmills, pp. 24-51. Birkinshaw, J., Ridderstrale, J., 1999. Fighting the corporate immune system: a process study of subsidiary initiatives in multinational corporations. International Business Review 8, $149-180$.

Burns, T., 1961. Micropolitics: mechanisms of institutional change. Administrative Science Quarterly 6, 257-281.

Crozier, M., Friedberg, D. (Eds.), 1980. Actors and Systems. The Politics of Collective Action. University of Chicago Press, Chicago.

Davison, S.C., Ekelund, B.Z., 2004. Effective team processes for global teams, in: Lane, H.W., Maznevski, M.L., Mendenhall, M.E., McNett, J. (Eds.), The Blackwell Handbook of Global Management: A Guide to Managing Diversity. Blackwell, Oxford, pp. 134-151.

Dickman, M., Harris, H., 2005. Developing career capital for global careers. The role of international assignments. Journal of World Business 40, 399-408.

Dörrenbächer, C., 2000. Between global market constraints and national dependencies. The internationalisation of the world leading telecommunication equipment manufacturers 1980-1995. Transnational Corporations 9 (3), 1-35.

Doz, Y., Prahalad, C.K, 1993. Managing DMNCs: a search for a new paradigm, in: Ghoshal, S., Westney, D.E. (Eds.), Organization Theory and the Multinational Corporation. MacMillan, Basingstoke, pp. 24-50.

Edwards, T., Ferner, A., 2002. The renewed 'American challenge': a review of employment practices in US multinationals. Industrial Relations Journal 33 (2), 94-111.

Edwards, T., Rees, Ch., Coller, X., 1999. Structure, politics and the diffusion of employment practices in multinationals. European Journal of Industrial Relations 5 (3), 286-306. 
Feldman, D.C., Thomas, A. 1992. Career management issues facing expatriates. Journal of International Business Studies 23 (2), 271-293.

Ferner, A., 2000. The underpinnings of 'bureaucratic' control systems: HRM in European multinationals. Journal of Management Studies 37 (4), 521-539.

Fischer, F., 2005. Revisiting organizational politics: the postempiricist challenge. Policy and Society, June, 1-23.

Forsgren, M., 1989. Managing the internationalization process: the Swedish case. Routledge, London.

Forsgren, M., 1990. Managing the international multi-centre firm: case studies from Sweden. European Management Journal 8, 261-267.

Forsgren, M., Holm, U., Johanson, J., 1995. Division headquarters go abroad - a step in the internationalization of the multinational corporation. Journal of Management Studies 32(4), 475-491.

Forsgren, M., Holm, U., Johanson, J., 2005. Managing the Embedded Multinational: A Business Network View. Edward Elgar, Cheltenham.

Frank, R.S., 1998. Political risk, in: Tung, R.L. (Ed.), The IEBM Handbook of International Business. Thomson Business Press, London, pp. 485-501.

Geppert, M., 2003. Sensemaking and politics in MNCs: a comparative analysis of vocabularies within the global manufacturing discourse in one industrial sector. Journal of Management Inquiry 12 (4), 312-329.

Geppert, M., Williams, K., 2006. Global, national and local practices in multinational corporations: towards a socio-political framework. International Journal of Human Resource Management, 17 (1), 49-69.

Geppert, M., Williams, K., Matten, D., 2003. The social construction of contextual rationalities in MNCs: An Anglo-German comparison of subsidiary choice. Journal of Management Studies 40 (3), 617-641. 
Ghoshal, S., Westney, E., 1993. Organization Theory and the Multinational Corporation. St. Martin’s Press, New York.

Hatch, M.J., 1997. Organization Theory: Modern, Symbolic and Postmodern Perspectives. Oxford University Press, Oxford.

Hardy, C., Clegg, S.R., 1996. Some dare call it power, in: Clegg, S.R., Hardy, C., Nord, W.R., Handbook of Organization Studies. Sage, London, pp. 622-641.

Harzing, A.-W., Sorge, A., 2003. The relative impact of country of origin and universal contingencies on internationalization strategies and corporate control in multinational enterprises: worldwide and European perspectives. Organization Studies 24 (2), 187-214.

Hollingsworth, J.R., Boyer, R., 1997. Coordination of economic actors and social systems of production, in: Hollingsworth, J.R., Boyer, R. (Eds.), Contemporary Capitalism: The Embeddedness of Institutions. Cambridge University Press, Cambridge, pp.1-47.

Husted, K., Michailova, S., 2002. Diagnosing and fighting knowledge sharing hostility. Organizational Dynamics, 31 (1), 60-73.

Kilduff, M., 1993. The reproduction of inertia in multinational corporations, in: Ghoshal, S., Westney, D.E. (Eds.), Organization Theory and the Multinational Corporation. MacMillan, Basingstoke, UK, pp. 259-274.

Kostova, T., Zaheer, S., 1999. Organizational legitimacy under conditions of complexity: the case of the multinational enterprise. Academy of Management Review 24 (1), 64-81. Kristensen, P.H., Zeitlin, J., 2001. The making of a global firm: local pathways to multinational enterprise, in: Morgan, G., Kristensen, P.H., Whitley, R. (Eds.), The Multinational Firm. Oxford University Press, Oxford, pp. 172-195.

Kristensen P.H., Zeitlin, J., 2005. Local Players in Global Games. The Strategic Constitution of a Multinational Corporation. Oxford University Press, Oxford. Lee, R., Lawrence, P., 1985. Organizational Behaviour. Politics at Work. Hutchinson, London. 
March, J.G., 1962. The business firm as a political coalition. The Journal of Politics 24, pp. 662-678.

Mintzberg, H., 1983. Power in and around Organizations. Prentice-Hall, Inc., Englewood Cliffs.

Morgan, G., 2001. The multinational firm: organizing across institutional and national divides, in: Morgan, G., Kristensen, P.H., Whitley, R. (Eds.), The Multinational Firm: Organizing Across Institutional and National Divides. Oxford University Press, Oxford, pp. $1-24$.

Morgan, G., Kristensen P.H., 2006, forthcoming. The contested space of multinationals: varieties of institutionalism: varieties of capitalism. Human Relations 59, Special Issue on 'Transnational institution building and the multinational corporation'.

Nohria, N., Ghoshal, S., 1997. The Differentiated Network: Organizing Multinational Corporations for Value Creation. Jossey-Bass, San Francisco.

Ortmann, G., 1988, Macht, Spiel, Konsens, in: Küpper, W., Ortmann, G. (Eds.), Mikropolitik. Rationalität, Macht und Spiele in Organisationen. Westdeutscher Verlag, Opladen, pp. 13-26.

Osland, J.S., 2004. Building community through change, in: Lane, H.W., Maznevski, M.L., Mendenhall, M.E., McNett, J. (Eds.), The Blackwell Handbook of Global Management: A Guide to Managing Diversity. Blackwell, Oxford, pp. 134-151.

Rothman, J., Friedman, V.J., 2001. Identity, conflict and organizational learning, in:

Dierkes, M., Berthoin Antal, A., Child, J., Nonaka, I. (Eds.), The Handbook of Organizational Learning and Knowledge. Oxford University Press, Oxford, pp. 582-597. Spar, D.L., 2001. National politics and domestic politics, in: Rugman, A.L., Brewer, T.S., The Oxford Handbook of International Business. Oxford University Press, Oxford, pp. 206231.

Stopford. J.M., Wells, L.T., 1972. Managing the Multinational Enterprise / Organization of the Firm and Ownership of the Subsidiaries. Basic Books, New York. 
Tempel, A., 2001, The Cross-National Transfer of Human Resource Management Practices in German and British Multinational Companies. Hampp, München/Mehring.

Weick, K., 1995. Sensemaking in Organizations. Sage, Thousand Oaks.

Welch, D.E., Welch, L.S., 2004. Getting published: the last great hurdle?, in: Marschan-

Piekkari, R., Welch, C. (Eds.), Handbook of Qualitative Research Methods for International Business. Edward Elgar, Cheltenham, pp. 551-569.

Williams, K., Geppert, M., 2006. Employment relations as a resource in the socio-political construction of transnational social spaces by multinational companies: evidence from German and British subsidiaries, in: Geppert, M., Mayer, M. (Eds.), Global, National and Local Practices in Multinational Companies. Palgrave, Basingstoke, pp. 38-60. 